\title{
MODEL FOR THE CORRECTION OF THE SPECIFIC GRAVITY OF BIODIESEL FROM RESIDUAL OIL
}

\author{
Tatiana Aparecida Rosa da Silva \\ Instituto Federal de Educação, Ciência e Tecnologia de São Paulo, \\ Campus Avaré, Brazil \\ E-mail: tatyqui2@yahoo.com.br \\ Douglas Queiroz Santos \\ Federal University of Uberlândia, Institute of Chemistry, Brazil \\ E-mail: quimicodouglas@yahoo.com.br \\ Ana Paula de Lima \\ Federal University of Uberlândia, Institute of Chemistry, Brazil \\ E-mail: analimaquimica@gmail.com \\ Waldomiro Borges Neto \\ Federal University of Uberlândia, Institute of Chemistry, Brazil \\ E-mail: wbn@iqufu.ufu.br \\ Submission: $27 / 03 / 2013$ \\ Accept: 03/04/2013
}

\begin{abstract}
Biodiesel is an important fuel with economic benefits, social and environmental. The production cost of the biodiesel can be significantly lowered if the raw material is replaced by a alternative material as residual oil. In this study, the variation of specific gravity with temperature increase for diesel and biodiesel from residual oil obtained by homogeneous basic catalysis. All properties analyzed for biodiesel are within specification Brazil. The determination of the correction algorithm for the specific gravity function of temperature is also presented, and the slope of the line to diesel fuel, methylic biodiesel (BMR) and ethylic biodiesel (BER) from residual oil were respectively the values $-0.7089,-0.7290$ and -0.7277 . This demonstrates the existence of difference of the model when compared chemically different fuels, like diesel and biodiesel from different sources, indicating the importance of determining the specific algorithm
\end{abstract}


INDEPENDENT JOURNAL OF MANAGEMENT \& PRODUCTION (IJM\&P)

http://www.ijmp.jor.br

v. 4, n. 1, January - June 2013.

ISSN: 2236-269X

DOI: 10.14807/ijmp.v4i1.65

for the operations of conversion of volume to the reference temperature.

Keywords: biodiesel, residual oil, correction algorithm, specific gravity.

\section{INTRODUCTION}

In recent years the demand for renewable fuels has greatly increased, is increasing the price of oil or by concern for the environment due to climate change induced by the use of fossil fuels, making renewable energy sources extremely important (BALAT and BALAT, 2010, DABDOUB et al., 2009, NAMASIVAYAM et al., 2010). In this context, biodiesel plays an important role, especially in Brazil, with economic benefits, social and environmental. Although the increased emission of nitrogen compounds, biodiesel provides the reduction of pollutants such as particulate matter, carbon monoxide, polycyclic aromatic hydrocarbons (carcinogenic compounds) and sulfur oxides in relation to petroleum diesel, based on the entire production cycle and consumption. The role of biodiesel is beneficial, contributing to the longevity and efficiency of diesel engines, serving markets that request a fuel cleaner and safer (ABU-JRAI et al., 2009, ALTUN et al., 2008, DEMIRBAS, 2009).

The cost reduction in the production of biodiesel becomes essential, assuming the raw material has a share in the cost of the final product above $80 \%$, therefore cheap raw materials such as residual oils and fats have attracted the attention of producers of biodiesel due to its low cost (HAAS et al., 2006). The recycling of frying oil as biofuel not only deprive an unwanted compound of the environment, but also allow the generation of an alternative energy source, renewable and less polluting waste which would be transformed into a source of energy (LAM et al., 2010).

For the production of biodiesel the technologic (BALAT and BALAT, 2010) most commonly used in the world is the trans esterification (ENCINAR et al., 2011, KNOTHE, 2005, SHARMA et al., 2008, WANG et al., 2007). The biodiesels' of various sources may be physico-chemical properties significantly different; by varying the fatty acid profile and the qualities of biodiesel produced by trans esterification reaction is influenced by productive route (VALENTE et al., 2011).

Specific gravity is one of the most important properties of fuels, because injection systems, pumps and injectors must deliver the amount of fuel precisely adjusted to provide proper combustion. It is an intensive property that is independent 
DOI: 10.14807/ijmp.v4i1.65

of the quantity, can be indicative of pure and can also be used to perform conversions by volume (ALPTEKIN and CANAKCI, 2008, CASTRO et al., 2005, TAT and VAN GERPEN, 2000, RODRÍGUEZ-ANTÓN et al., 2008).

In Brazil, measure the volume of fuel to generate billing commercial transactions is performed at $20.0{ }^{\circ} \mathrm{C}$ (reference temperature), such as loading and unloading operations occur at ambient temperature it is necessary to convert the environment volume for the volume at the reference temperature(SANTOS and VIEIRA, 2010). The ABNT NBR 15512 recommends that to convert the specific gravity and volume to the reference temperature, the table is used for derivatives of petroleum.

Data conversion of specific gravity were obtained in the 70's, where resources were smaller, the equipment were not as sensitive and not had so many varieties of fuels and biofuels. Furthermore, it is important to note that since this is a table prepared for derivatives of petroleum is a big difference in chemical structure, on the one hand hydrocarbons (petroleum) and other alkyl esters (biodiesel).

With the inclusion of biodiesel in Brazil's energy matrix is necessary to know a mathematical algorithm for the correction of specific gravity, to avoid the use of current models lagged as recommended by the ABNT NBR 15512.

This study aims to determine the mathematical algorithm to correct the specific gravity of methylic and ethylic biodiesel from residual oil and compare it with diesel.

\section{EXPERIMENTAL}

Biodiesel used was obtained by ethylic trans esterification (BER) and methylic alkaline (BMR), using as raw material the residual oil. The reaction conditions were rotating at $80 \mathrm{rpm}$, the molar ratio alcohol: oil 7:1, catalyst, potassium hydroxide at a concentration of $1.7 \mathrm{wt} \%$ being to ethylic temperature of $35^{\circ} \mathrm{C}$ and reaction time of 30 minutes and the methyl temperature of $48^{\circ} \mathrm{C}$ and reaction time 60 minutes. After the alkaline transesterification reaction, the system resulted in two phases with impure biodiesel being formed at the top and glycerine at the bottom. The biodiesel was removed from the mixture, adjusted the $\mathrm{pH}$ to near 7 and then washed 3 times with water at $80{ }^{\circ} \mathrm{C}$. Residual water was removed by rotary evaporation and the biodiesel obtained. 
DOI: 10.14807/ijmp.v4i1.65

The methods used to analyze the biodiesel were: acidity ASTM D-664, humidity ASTM D-6304, viscosity ASTM D-445 e D-446, oxidative stability EN 14112, flash point ASTM D-93, specific gravity ASTM D-4052, peroxide index NBR 9678, free glycerol NBR 15771 and carbon residue ASTM 4730. The specific gravity was determined on a Kyoto density/specific mass meter (model DA-500), according to ASTM D-4052, within the temperature range of 10 to $50{ }^{\circ} \mathrm{C}$ at intervals of $5{ }^{\circ} \mathrm{C}$. The calibration was performed with water, the default uncertainty of expanded of which is $\pm 0.01 \mathrm{~kg} \mathrm{~m}^{-3}$, in order to ensure the reliability of the metrological experiments.

Using simple linear regression of $\mu$ versus $T$ it was possible to determine the mathematical algorithms for the correction of the specific gravity of ethylic (BER) and methylic (BMR) biodiesels obtained from residual oil. The collected data were analyzed using the Statistica 7.0 StatSoft.

\section{RESULTS AND DISCUSSION}

The physical-chemical properties of biodiesel are directly related to fuel quality (DABDOUB et al., 2009). In the characterization of methylic and ethylic biodiesel from residual oil, were performed some analyzes shown in Table 1.

Table 1. Physical and chemical properties of methylic (BMR) and ethylic (BER) biodiesel fom residual oil

\begin{tabular}{llllll}
\hline PROPERTIES & UNITS & BMR & BER & ANP & METHOD \\
\hline Water & $\mathrm{mg} \mathrm{kg}^{-1}$ & 127.8 & 129.5 & $<500$ & ASTM D-6304 \\
\hline Acidity & $\mathrm{mg} \mathrm{KOH} \mathrm{g}^{-1}$ & 0.27 & 0.37 & $<0.50$ & ASTM D-664 \\
\hline Free glycerol & $\%$ mass & $8.55 \times 10^{-5}$ & $1.07 \times 10^{-4}$ & $<0.02$ & NBR 15771 \\
\hline Specific gravity & $\mathrm{kg} \mathrm{m}^{-3}$ & 880.7 & 877.1 & $850-900$ & ASTM D-4052 \\
\hline Flash Point & ${ }^{\circ} \mathrm{C}$ & 176 & 175 & $>100$ & ASTM D-93 \\
\hline Viscosity & $\mathrm{mm}^{2} \mathrm{~s}^{-1}$ & 4.2 & 4.5 & $3.0-6.0$ & ASTM D-445 \\
\hline \multicolumn{1}{c}{ Carbon residue } & $\mathrm{wt} \%^{\text {Peroxide value }}$ & 0.003 & 0.011 & $<0.050$ & ASTM 4730 \\
\hline Oxidative Stability & hours & 4.11 & 3.70 & --- & NBR 9678 \\
\hline
\end{tabular}

All results meet the specification of ANP (2012) and the methylic and ethylic biodiesel have slightly different values due to the slight difference in the structure of methylic and ethylic esters.

Moisture is a very important parameter for the quality of biodiesel, since water 
DOI: 10.14807/ijmp.v4i1.65

can cause an unwanted reaction (hydrolysis) decompose biodiesel and producing free fatty acids, which can cause the development of engine problems. As the moisture content, the acidity of a fuel is an essential factor control since the presence of free fatty acids may trigger a whole oxidation of the fuel, and is also responsible for oxidation of the internal engine parts, causing corrosion and formation deposits. The acidity is also within the specification (KNOTHE, 2007).

According to the results, the washing procedure was effective to remove free glycerin. Fuels with excess free glycerin cause clogging of fuel filters, deposition of glycerol in the storage tanks and therefore problems in the combustion engine. Moreover, the burning of glycerin leads, among other toxic compounds, acrolein is a carcinogen aldehyde can cause respiratory problems for long periods inspired case as in traffic jams inside tunnels, something frequently in large cities (ATADASHI et al., 2010).

The fluid dynamic properties of a fuel, which are important as regards the operation of injection compression engines (diesel engines), are the viscosity and specific gravity. These properties have great influence on the movement and fuel injection (MORÓN-VILLARREYES et al., 2007, JORGE et al., 2005).

The parameter specific gravity is within the limits accepted by ANP for both, the ethylic and methylic biodiesel of residual oil. There an essential property affecting the development of the engine, since fuel air ratio in the combustion chamber are affected by it (HOEKMAN et al., 2011). The flash point, which is the temperature at which a flammable liquid becomes in the presence of a flame or sparks. This property is of importance only as regards the safety of transport, handling and storage, and may indicate contamination by alcohol. Methylic biodiesel was lower than that of ethylic biodiesel probably due to the length of the carbon be smaller, the value found is close to the reported by Dantas and colleagues (ATADASHI et al., 2010, DANTAS et al., 2011).

A major objective of biodiesel production is to reduce the viscosity of triglycerides to values close to the diesel, because this property is an important parameter for the injection system of vehicles and the fuel pumping system. Both biodiesels meet the specification stating different viscosity of diesel oil (DANTAS et al., 2011). 
DOI: 10.14807/ijmp.v4i1.65

The burning of the esters produced was almost complete with only minimal residual negligible smaller than the maximum required by ANP, providing a fuel quality. These residues can cause the formation of sludge in the region of the nozzle, which can cause problems in operation and, in severe cases, irreparable damage to internal parts.

Although not a requirement of the fuel analysis of the peroxide have proven to be an interesting study object, since the oxidation reaction is often suggested by the increase in peroxide value over the storage period.

The biodiesel showed good oxidative stability. Fuel can lead to unstable increased viscosity and the formation of gums, sediment, or other deposits. More ideas on these degradation processes are provided in reviews recent literature on the subject (HOEKMAN et al., 2011).

Table 2, there are measured values of specific gravity as a function of temperature $\left(10\right.$ to $50{ }^{\circ} \mathrm{C}$ ) methylic and ethylic biodiesel of residual oil, BMR and BER, respectively and diesel. The specific gravity to $20^{\circ} \mathrm{C}$ for methylic and ethylic esters from residual oil of respectively $880.7 \mathrm{~kg} \mathrm{~m}^{-3}$, and $877.1 \mathrm{~kg} \mathrm{~m}^{-3}$, and $855.2 \mathrm{~kg}$ $\mathrm{m}^{-3}$ to diesel oil to $293.15 \mathrm{~K}$. These values found for the biodiesels are close to values found in literature for different materials, ranging from 873 to $883 \mathrm{~kg} \mathrm{~m}^{-3}$. The slight difference is due to the change of the raw material used, shows that different variations in volume, according to each molecule of biodiesel.

Table 2. Measured values of specific gravity as a function of temperature of the

\begin{tabular}{llll}
\multicolumn{4}{c}{ biodiesels' from residual oil and diesel oil } \\
\hline $\mathrm{T} /{ }^{\circ} \mathrm{C}$ & BER $\left(\mathrm{kg} \mathrm{m}^{-3}\right)$ & BMR $\left(\mathrm{kg} \mathrm{m}^{-3}\right)$ & DIESEL $\left(\mathrm{kg} \mathrm{m}^{-3}\right)$ \\
\hline $\mathbf{1 0}$ & 884.4 & 888.1 & 862.2 \\
\hline $\mathbf{1 5}$ & 880.8 & 884.4 & 858.7 \\
\hline $\mathbf{2 0}$ & 877.1 & 880.7 & 855.2 \\
\hline $\mathbf{2 5}$ & 873.4 & 877.0 & 851.7 \\
\hline $\mathbf{3 0}$ & 869.8 & 873.5 & 848.1 \\
\hline $\mathbf{3 5}$ & 866.2 & 869.8 & 844.6 \\
\hline $\mathbf{4 0}$ & 862.6 & 866.2 & 841.0 \\
\hline $\mathbf{4 5}$ & 858.9 & 862.5 & 837.5 \\
\hline $\mathbf{5 0}$ & 855.3 & 858.9 & 833.9 \\
\hline
\end{tabular}


Order to facilitate trade in these products, value all business operations and establish the prices to the volumes referred to a reference temperature of $20.0^{\circ} \mathrm{C}$ it is necessary to fix the volume of ambient temperature to the reference temperature in Brazil, being needed for this mathematical algorithm to determine this correction.

Currently the Brazilian standard ABNT NBR 15512 of 1970 provides that for correction of volume and specific gravity to the temperature of reference is used a single table. This standard is applied to petroleum products coming from nonrenewable sources and how old does not include chemically different compounds such as biodiesel, a fuel cleaner and come from a renewable source. The calculation of the correct volume is important for dealers and biodiesel industries; because they pay the price per liter of biofuel and this calculation must be in accordance to the raw material used.

From the data in Table 2 was prepared Figure 1 to determine mathematical algorithm. Note that the specific gravity is a decreasing linear function of temperature and shows that the slope sensitivity to temperature being the diesel fuel, BMR and BER these values were respectively, $0.7089 \mathrm{~kg} \mathrm{~m}^{-3} \mathrm{~T}^{-1}, 0.7290 \mathrm{~kg} \mathrm{~m}^{-3} \mathrm{~T}^{-1}$ and $0.7277 \mathrm{~kg} \mathrm{~m}^{-3} \mathrm{~T}^{-1}$.

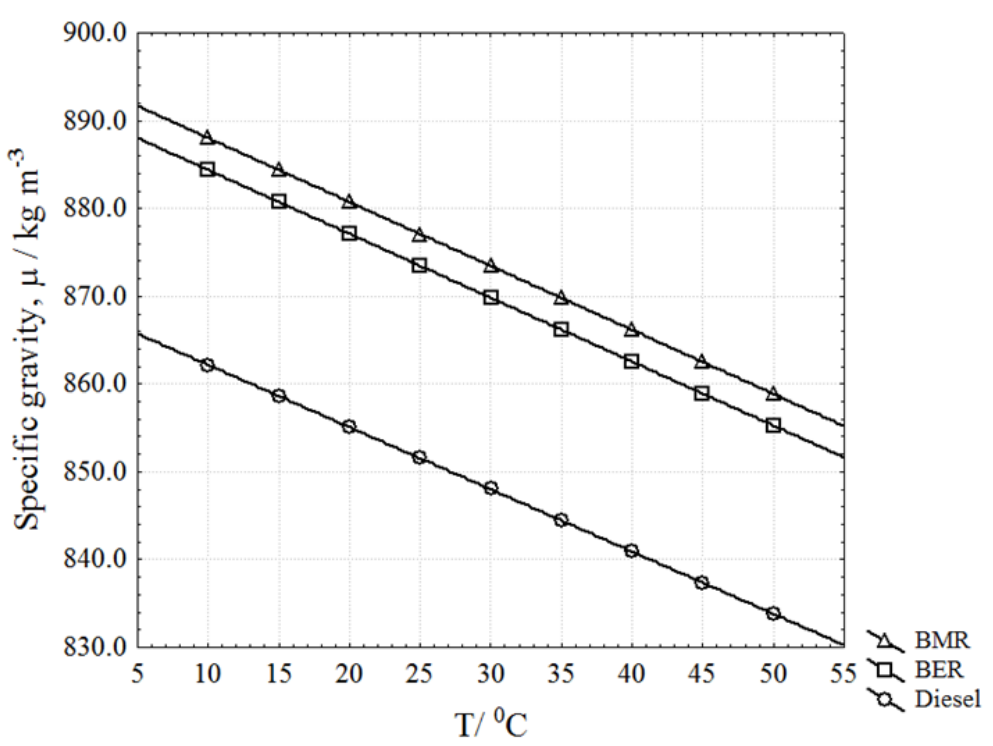

Figure 1. Linear regression of specific gravity versus temperature of diesel fuel, BMR and BER.

Statistical methods allow to characterize the experimentally data obtained and evaluate the quality of these data on the assumption that the random errors 
DOI: 10.14807/ijmp.v4i1.65

contained in the analytical results follow in most cases a Gaussian distribution, or normal. Through statistical analysis of linear regression of the data specific gravity is possible to accept the mathematical algorithm and provide through a simple statistical test, called F-test if the regression is significant within a confidence level (SKOOG et al., 2007).

Residual analysis is essential to evaluate the fit of any model. A model that leaves much waste is a bad model. In an ideal model would be no waste, ie, the results observed were equal to those (MONTGOMERY, 2001). It can be found in Figure 2 for both biodiesels alternating vertical deviations of points about straight line are called residues, which can be concluded that the variance of errors is constant and that there is the presence of systematic errors.
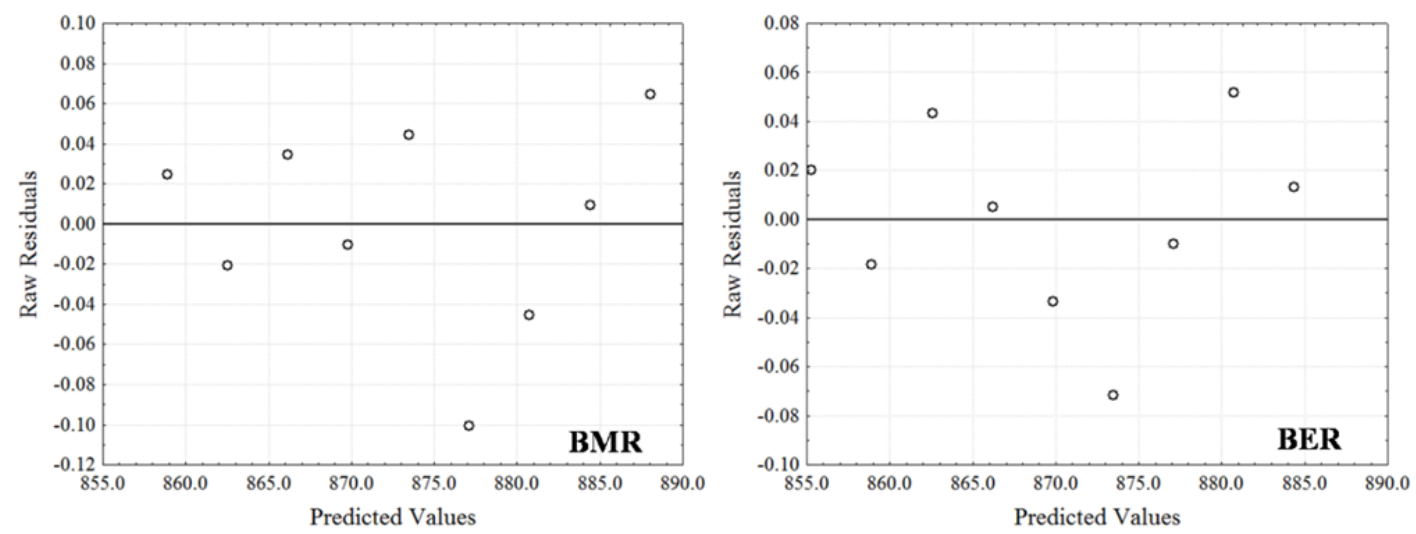

Figure 2. Residue versus the predicted value from data specific gravity for BMR and BER.

Data from methylic and ethylic biodiesel behave near normal distribution, according to Figure 3, showing adaptation of the mathematical model the system studied.
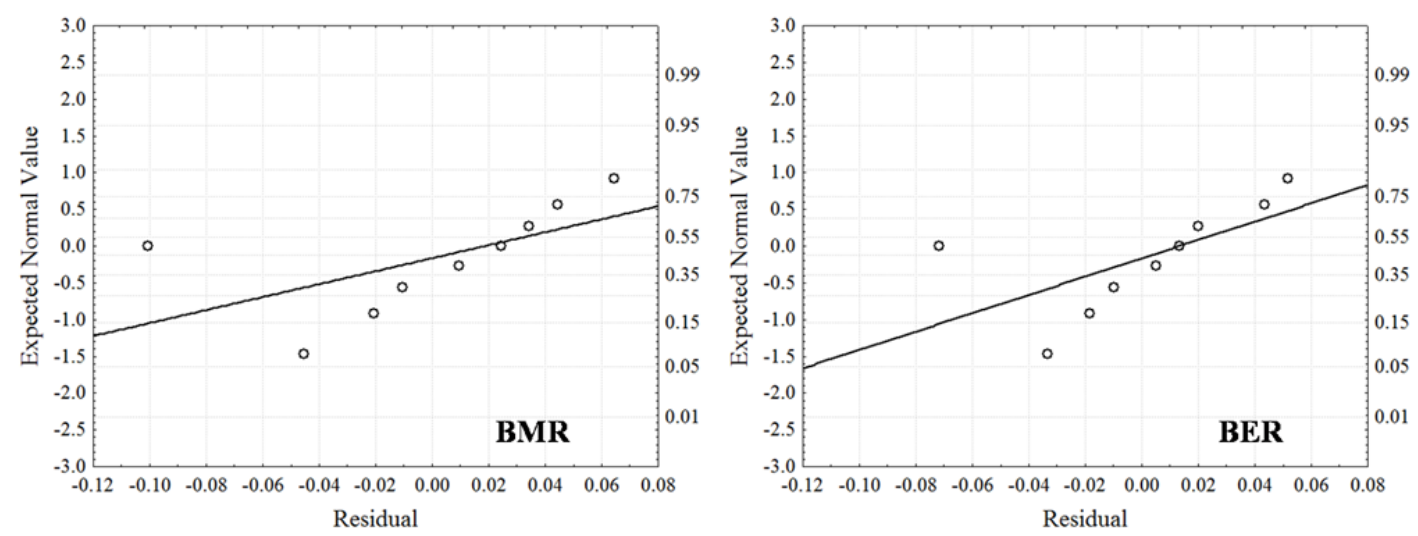
DOI: $10.14807 /$ ijmp.v4i1.65

Figure 3. Distribution of the residuals for data specific gravity about the line indicating normal to BMR and BER.

Table 3 shows the statistical linear regression. The model fit was also expressed by a coefficient of determination $\left(R^{2}\right)$, equal to 0.999 for both cases, as the $R^{2}$ value is near the theoretical, it can be said that modeling was adequate and the sensitivity of the model (slope) whose values are \pm 0.0033 for BMR and \pm 0.0025 for BER. From analysis of variance (ANOVA) determined the value of the $F$ statistic, the $F_{\text {calculated }}$ values are larger than the $F_{\text {tabulated, }}$ to $B M R F_{\text {calculated }}=2.69 \times 10^{5}$ and to BER $\mathrm{F}_{\text {calculated }}=4.70 \times 10^{5}$, showing that the model is predictive and significant at a confidence level of $95 \%$, and no reported lack of fit within the range evaluated.

Table 3. Data linear regression to diesel fuel, BER and BMR for determination algorithm to correct specific gravity

\begin{tabular}{lllllll}
\multirow{2}{*}{ SAMPLE } & \multicolumn{2}{l}{ DATA REGRESSION } & & & \\
\cline { 2 - 3 } & Linear Coefficient & Slope & $\boldsymbol{R}^{2}$ & $\boldsymbol{F}_{\text {calculated }}$ & $\boldsymbol{F}_{\text {tabulated }}$ & $\boldsymbol{p}$-value \\
\hline Diesel & 869.27 & -0.7089 & $99.99 \%$ & $9.3 \times 10^{5}$ & 5.59 & $4.52 \times 10^{-18}$ \\
\hline BER & 891.70 & -0.7277 & $99.99 \%$ & $4.7 \times 10^{5}$ & 5.59 & $3.71 \times 10^{-18}$ \\
\hline BMR & 895.30 & -0.7290 & $99.99 \%$ & $2.7 \times 10^{5}$ & 5.59 & $2.61 \times 10^{-11}$ \\
\hline
\end{tabular}

The linear coefficient represents physically the initial specific gravity, therefore, the algorithms for correction of volume adopt the following Equations 2-4 for methylic and ethylic biodiesel and diesel, respectively, in the temperature range studied:

$$
\begin{array}{ll}
\mu_{T}=\mu_{\text {measured }}-0.7290 \times\left(T-T_{\text {measured }}\right) & \text { Equation 2 } \\
\mu_{T}=\mu_{\text {measured }}-0.7277 \times\left(T-T_{\text {measured }}\right) & \text { Equation 3 } \\
\mu_{T}=\mu_{\text {measured }}-0.7089 \times\left(T-T_{\text {measured }}\right) & \text { Equation 4 }
\end{array}
$$

Comparing the slope of the BMR, the BER and diesel perceive a considerable difference between them and the values determined by Yoon and colleagues(Yoon, 2008). The difference found when comparing different sources of fuels such as diesel and biodiesel, suggests that the algorithm has to be determined for each fuel, which differs from that recommended by the ABNT NBR 15512 that evaluates the correction of the specific gravity of biodiesel using table of petroleum products. 
ISSN: 2236-269X

DOI: 10.14807/ijmp.v4i1.65

\section{CONCLUSIONS}

This work it was possible the modeling algorithm to correct specific gravity of biodiesel from residual oil. According to statistical data, the mathematical algorithm to correct specific mass is a linear model and predictive and significant at a confidence level of $95 \%$, described by the equations presented with slope of 0.7089 for diesel oil, 0.7290 for methylic (BMR) and 0.7277 for the ethylic biodiesel (BER) from residual oil.

The results show that biodiesel from residual oil presents thermal behavior different from that of diesel and biodiesel, and between biodieseis there is a subtle difference. Importantly, the ABNT NBR 15512 recommends that the bases and distribution terminals to correct specific gravity at temperature $20{ }^{\circ} \mathrm{C}$ should be based on the conversion table used for petroleum products and in this work demonstrate that this approach is not the most appropriate for the matrix of biodiesel from residual oil.

\section{ACKNOWLEDGMENT}

The authors thank FAPEMIG and CNPq for financial support and scholarships.

\section{REFERENCES}

(2012) Sítio da Agência Nacional de Petróleo, Gás Natural e Biocombustíveis - ANP. Resolução $n^{\circ} 7$, de 19 de março de 2008.

ABU-JRAI, A., RODRÍGUEZ-FERNÁNDEZ, J., TSOLAKIS, A., MEGARITIS, A., THEINNOI, K., CRACKNELL, R. F. \& CLARK, R. H. (2009) Performance, combustion and emissions of a diesel engine operated with reformed EGR. Comparison of diesel and GTL fuelling. Fuel, 88, 1031-1041.

ALPTEKIN, E. \& CANAKCI, M. (2008) Determination of the density and the viscosities of biodiesel-diesel fuel blends. Renewable Energy, 33, 2623-2630.

ALTUN, S., BULUT, H. \& ÖNER, C. (2008) The comparison of engine performance and exhaust emission characteristics of sesame oil-diesel fuel mixture with diesel fuel in a direct injection diesel engine. Renewable Energy, 33, 1791-1795.

ATADASHI, I. M., AROUA, M. K. \& AZIZ, A. A. (2010) High quality biodiesel and its diesel engine application: A review. Renewable and Sustainable Energy Reviews, 14, 1999-2008.

BALAT, M. \& BALAT, H. (2010) Progress in biodiesel processing. Applied Energy, $87,1815-1835$.

CASTRO, M. P. P., ANDRADE, A. A., FRANCO, R. W. A., MIRANDA, P. C. M. L., STHEL, M., VARGAS, H., CONSTANTINO, R. \& BAESSO, M. L. (2005) Thermal properties measurements in biodiesel oils using photothermal techniques. Chemical Physics Letters, 411, 18-22. 
DABDOUB, M., BRONZEL, J. \& RAMPIM, M. (2009) Biodiesel: visão crítica do status atual e perspectivas na academia e na indústria. Química Nova, 32, 776-779.

DANTAS, M. B., ALBUQUERQUE, A. R., BARROS FILHO, A. K., RODRIGUES FILHO, M. G., ANTONIOSI FILHO, N. R., SINFRÔNIO, F. S. M., ROSENHAIM, R., SOLEDADE, L. E. B., SANTOS, I. M. G. \& SOUZA, A. G. (2011) Evaluation of the oxidative stability of corn biodiesel. Fuel, 90 773-778.

DEMIRBAS, A. (2009) Political, economic and environmental impacts of biofuels: A review. Applied Energy, 86, S108-S117.

ENCINAR, J. M., SÁNCHEZ, N., MARTíNEZ, G. \& GARCÍA, L. (2011) Study of biodiesel production from animal fats with high free fatty acid content. Bioresource Technology, 102, 10907-10914.

HAAS, M. J., MCALOON, A. J., YEE, W. C. \& FOGLIA, T. A. (2006) A process model to estimate biodiesel production costs. Bioresource Technology, 97, 671-678.

HOEKMAN, S. K., BROCH, A., ROBBINS, C., CENICEROS, E. \& NATARAJAN, M. (2011) Review of biodiesel composition, properties, and specifications. Renewable and Sustainable Energy Reviews, 16, 143-169.

JORGE, N., SOARES, B. B. P., LUNARDI, V. M. \& MALACRIDA, C. R. (2005) Alterações físico-químicas dos óleos de girassol, milho e soja em frituras. Química Nova, 28, 947-951.

KNOTHE, G. (2005) Dependence of biodiesel fuel properties on the structure of fatty acid alkyl esters. Fuel Processing Technology, 86, 1059-1070.

KNOTHE, G. (2007) Some aspects of biodiesel oxidative stability. Fuel Processing Technology, 88, 669-677.

LAM, M. K., LEE, K. T. \& MOHAMED, A. R. (2010) Homogeneous, heterogeneous and enzymatic catalysis for transesterification of high free fatty acid oil (waste cooking oil) to biodiesel: A review. Biotechnology Advances, 28, 500-518.

MONTGOMERY, D. C. (2001) Design and Analyses of Experiments, New York, Wiley.

MORÓN-VILLARREYES, J. A., SOLDI, C., DE AMORIM, A. M., PIZZOLATTI, M. G., DE MENDONÇA JR, A. P. \& D'OCA, M. G. M. (2007) Diesel/biodiesel proportion for by-compression ignition engines. Fuel, 86, 1977-1982.

NAMASIVAYAM, A. M., KORAKIANITIS, T., CROOKES, R. J., BOB-MANUEL, K. D. H. \& OLSEN, J. (2010) Biodiesel, emulsified biodiesel and dimethyl ether as pilot fuels for natural gas fuelled engines. Applied Energy, 87, 769-778.

RODRÍGUEZ-ANTÓN, L. M., APARICIO, C., GUIGNON, B. \& SANZ, P. D. (2008) Volumetric properties at high pressure of waste oil methyl ester compared with diesel oil. Fuel, 87, 1934-1940.

SANTOS, A. D. Q. \& VIEIRA, D. F. (2010) Determinação de coeficiente de expansão térmica do biodiesel e seus impactos no sistema de medição volumétrico. Eclética Química, 35, 107-112.

SHARMA, Y. C., SINGH, B. \& UPADHYAY, S. N. (2008) Advancements in development and characterization of biodiesel: A review. Fuel, 87, 2355-2373. 
SKOOG, D. A., WEST, D. M., HOLLER, J. F. \& CROUCH, S. R. (2007)

Fundamentos de Química Analítica. Tradução da $8^{a}$ ed. norte-americana, São Paulo, Editora Thomson

TAT, M. \& VAN GERPEN, J. (2000) The specific gravity of biodiesel and its blends with diesel fuel. Journal of the American Oil Chemists Society, 77, 115-119.

VALENTE, O. S., PASA, V. M. D., BELCHIOR, C. R. P. \& SODRÉ, J. R. (2011) Physical-chemical properties of waste cooking oil biodiesel and castor oil biodiesel blends. Fuel, 90, 1700-1702.

WANG, Y., OU, P. L. S. \& ZHANG, Z. (2007) Preparation of biodiesel from waste cooking oil via two-step catalyzed process. Energy Conversion and Management, 48, 184-188.

YOON, S. H. P., S. H.; LEE, C. S. (2008) Experimental Investigation on the Fuel Properties of Biodiesel and Its Blends at Various Temperatures. Energy \& Fuels, 22, 652-656. 